\title{
The Potential of Using Indigenous Pesticidal Plants for Insect Pest Control to Small Scale Farmers in Africa
}

\author{
Angela G. Mkindi, Kelvin M. Mtei, Karoli N. Njau, Patrick A. Ndakidemi \\ School of Materials, Energy, Water and Environmental Sciences (MEWES), The Nelson Mandela \\ African Institution of Science and Technology, Arusha, Tanzania \\ Email: mkindia@nm-aist.ac.tz
}

Received 15 October 2015; accepted 11 December 2015; published 14 December 2015

Copyright (C) 2015 by authors and Scientific Research Publishing Inc.

This work is licensed under the Creative Commons Attribution International License (CC BY). http://creativecommons.org/licenses/by/4.0/

c) (i) Open Access

\begin{abstract}
Pesticidal plants are scientifically proven for their effectiveness in controlling insect pests. Their activity is enhanced by active compounds contained, which are known for their repellant and antifeedant potentials to the insects. Use of pesticidal plants by local small scale farmers has been a point of concern following information that majority of farmers do not widely use pesticidal plants despite of an indigenous knowledge that they possess. Improvement of the technologies used by local farmers in previous times, that are easy and effective need to help farmers abstain from the use of synthetic pesticides that are detrimental to the environment and to their own health. This paper reviews the potentiality of pesticidal plants to small holder farmers. It also gives the status of pesticidal plants use, their possible effectiveness against insect pests, persistence as well as the knowledge that indigenous people possess in their use. Again, the paper suggests the need for more instrumental research on practical improvement of indigenous knowledge on the use of pesticidal plants with scientific evidences.
\end{abstract}

\section{Keywords}

Insect Pests, Pesticidal Plants, Environment, Health, Indigenous Knowledge

\section{Introduction}

The awareness and use of pesticidal plants in developing countries is growing over time following the scientific proof of damages caused by synthetic pesticides.

In developing countries where massive poisoning due to the use of pesticides is increasing and posing envi-

How to cite this paper: Mkindi, A.G., Mtei, K.M., Njau, K.N. and Ndakidemi, P.A. (2015) The Potential of Using Indigenous Pesticidal Plants for Insect Pest Control to Small Scale Farmers in Africa. American Journal of Plant Sciences, 6, $3164-3174$. http://dx.doi.org/10.4236/ajps.2015.619308 
ronmental and health risks; use of pesticidal plants is gaining priority [1].

Pesticidal plants as an alternative to synthetic pesticides are recognized because of their non-cytotoxicity, easy of biodegradability and simulator nature of host metabolism [2] [3]. Compounds in pesticidal plants break down rapidly, making them more environmental friendly compared with synthetic compounds [4]. Therefore, they are a good alternative in crop production.

Across Africa, there is a massive availability of plants which have been identified for their pesticidal effects [5] [6]. Their growth, proliferation and cheap availability encourages a history of their use [5]. It is understood that the culture of relying on botanical pesticides vanished after the introduction of synthetic DDT in the 1940s [7]. By the 1960s, their adverse impacts on the environment and human health's were becoming evident [8]. Reasons for the use of synthetic pesticides are their immediate impacts against pests which with time resulted into trading of agricultural products with pesticides residues [9] [10]. This scenario is realized to have severe impacts to environment and to people's health [11] because such pesticides are used improperly and without protective gears. Use of pesticidal plants is hence beneficial for the reasons that firstly, they are relatively cheaper and easily available and secondly their formulations are less persistent to the environment and have less toxic effects [12]. Therefore, innovation in the use of pesticidal plants is a means of reducing production cost and improving existing knowledge on the use of the pesticidal plants in agricultural pest control.

Since long in history, small holder farmers have been knowledgeable on the use of pesticidal plants. In many developing nations, especially in parts of Africa, there are several indigenous groups who despite of the available knowledge on the usefulness of botanical pesticides have not fully accepted the use of pesticidal plants as a more environmentally friendly and cost-effective alternative [13]-[15]. In India [11] reported that only $2.89 \%$ of the bio pesticides used in India that are registered between 2005 and 2011, there are only 12 types of plant botanical pesticides. Generally, there is a massive research on plant extracts against insect pests that have not been communicated to local farmers, hence this appears to be a major reason for farmers not to use the technology [16].

Conversely, there are other literatures that reported the potential use of crude extracts, simply prepared and to great extent less concentrated to amounts that turn more toxic [1]. The objective of this review is to argue for more direct investment in research that can support the use of simply prepared plant extracts that have shown positive impacts against insect pests in terms of ease of use, compared with results from laboratory bioassays.

\section{Review Method}

Information in this paper is identified through Mendeley and Google scholar databases using key words like "synthetic pesticides and health", "indigenous knowledge and botanical pesticides", "efficacy of botanical pesticides", agriculture, Pollinators and environment that were used interchangeably for a clear information searching. Studies obtained focused on the impacts of synthetic pesticides to pollinators, human beings and environment, indigenous knowledge that rural small holders possess on pesticidal plants use in agricultural production as well as scientific information on the efficacy of various plant species against insect pests and diseases.

\section{An Overview of Pesticidal Plants Use Research}

Pesticidal plants compounds can naturally degrade easily in the environment hence rendering them less persistent [2]. Compounds from the plants are reported to break down into harmless compounds within hours or days [12]. Literatures indicate effects of climate factors which are daily average temperature and relative humidity in a sense that persistence of the compounds, reduce with their increase [17]. Being less persistent, these compounds are important in the environment as they pose less harm to non-target organisms. However, plants contain a mixture of chemicals that may have similar or antagonistic activities [18]. There is less information on the extent of breakdown or rather the persistence of each chemical in a mixture.

Breakdown of the compounds in hours or days is not enough to justify persistence of the chemicals and hence more information on time length that these chemicals persist in the environment is required.

Pesticidal plants application rates, persistence of the compounds in the environment and the preparation mechanisms indicate important aspects in the use of pesticidal plants in agriculture. Literatures have reported varied intervals of application of extracts such as three times throughout a growing season [19], twice for the season [20] and fifteen days intervals [21]. Contrary to synthetic pesticides that can last longer in the environment, 
pesticidal plants require more frequency if they are to work best. However, intervals for different plants in different seasons variations stipulated by [19]-[21] offers a chance to study about the persistence, and favorable time intervals that will be effective for the control of the pests without causing damages to non-target organisms and environment.

\subsection{Importance of Enhancing Small Scale Farmer's Knowledge in Africa on the Use of Pesticidal Plants in Controlling Agricultural Pests}

Pesticidal plants are proven to be perfect alternative against insect pests. For many years, indigenous Africans have been using the available pesticides at their disposal from plants and other organisms for different purposes including insect pest control [22]-[24]. However, findings from the developing countries show that small scale farmers suffer from poor knowledge on the use of introduced synthetic pesticides [25]-[27] and this is associated with detrimental effects to them and the environment. Therefore, research on pesticidal plants is needed to strengthen local knowledge that farmers have been aware of since long time in history.

In Africa, many of the pesticidal plants are found without difficulty. For example, they grow in the wild or even at homesteads and in farm boundaries. In this case, there is almost no cost of growing the plants. Therefore, it is worth promoting their use because synthetics have negative impacts as they are costly to eco-health and the economy [28]-[30]. A better choice to help growth of African agriculture would be to start from the baseline knowledge on pesticidal plants of the Africans themselves. This can be achieved through the improvement of the available knowledge on the use of pesticidal plants that would even disappear if not used and disseminated widely.

\subsection{Environmental and Human Health Impacts of Synthetic Pesticides}

Synthetic pesticides are known for their toxicity to the environment and to non-target organisms including wildlife, insects and human beings [31] [32]. Organochlorines, organophosphate and carbamates are the major groups of chemicals that are used as synthetic pesticides in developing countries despite the ban of others like DDT [33]. Their impacts threaten the food safety systems [34], human health [35] [36] and the environment.

Synthetic pesticides have been reported to reduce population among birds [33], and insects [37] [38]. The fact that synthetic pesticides are less selective treatments to insects in agro ecosystem practices gives a caution on the impacts that pesticides may have to non-target and beneficial insects [39]. Human beings are strongly affected during application and handling of the chemicals in the farms. Reports have revealed several types of cancer that results from improper use of synthetic pesticides such as Leukemia, Lung cancer, Pancreatic cancer, Colon and Rectal cancer, Lymphohematopoietic cancer, on-Hodgkin lymphoma, Bladder cancer, Breast cancer, multi Plemyeloma, Prostate cancer, Kidney cancer and Oral cavity cancer [40]. Pesticides are reported to enter into the cells and alter cell's cycles and hence resulting into some cancer [32]. Pesticides are also known for the ability to disrupt endocrine systems in humans and wildlife [41] [42]. Apart from cancer; skin pill off, hardness in breathing, stomach ache and vomiting as well as farmers collapsing have also affected users [43]. These effects then result to high health costs [44].

Generally, environmental organisms including plants, fish, birds, snakes and insects are affected massively. Farmers in Malaysia reported 80\% reduction in number of fish in two cropping seasons during a study conducted to identify impacts of pesticides in paddy farming [42]. Studies also show biota uptake of pesticides [25] which also imply soils contamination. There are therefore more detrimental effects caused by using synthetic pesticides for various agricultural purposes.

\subsection{Indigenous Knowledge on the Use of Pesticidal Plants for Field Control of Insect Pests}

Indigenous knowledge refers to the informal knowledge, skills and practices that are obtained not in schools, universities and research institutes but rather in local heritable ways normally in rural areas [45]. Developing countries are rich in such knowledge [46]. Indigenous knowledge on insect pest control is perceived as important because it was witnessed as useful in food security and survival of the users long before the invention of synthetic pesticides [45]. However, maintenance of the indigenous knowledge is found to be difficult because the majority of farmers have turned to modern agriculture that involves use of synthetic pesticides. 
Pesticidal plants have been used for more than 150 years ago [47]. Majority of African small holder farmers have been using various botanical pesticides to control insect pests. For example, in the Victoria basin in Uganda, farmers have used Capsicum frutescens, Tagetes spp., Nicotiana tabacum, Cypressus spp., Tephrosia vogelii, Azadirachta indica, Musa spp., Moringa oleifera, Tithonia diversifolia, Lantana camara, Phytollacca dodecandra, Vernonia amygdalina, Aloe spp., Eucalyptus spp., [22]. In addition to the pesticidal plants, farmers in Tanzania have been using other products such as cow's urine, cow dung, and ashes [23]. However, in these areas, there exists little information that this knowledge is used in an effective way in comparison to ancient practices. Research based efforts need to be undertaken to retrieve the knowledge.

During farming, indigenous knowledge in insect pest control involves direct spraying, intercropping pesticidal plants with the crops to be protected, and also using the botanicals based on the synthetic formulations [48]. Researchers have come up with some application techniques. This includes: the use of the freshly ground leaves, mixed and soaked overnight [19] [49]. Also, boiling plant parts and adding soap for extraction [14] has been practiced. [19] used fresh leaves pounded and mixed with water and $0.1 \%$ soap to make $3 \% \mathrm{w} / \mathrm{v}$ of the extract. [21] used another technique where sun dried plant materials were soaked in acetone and stirred for 30 minutes. Thereafter the mixture was left for 24 hours, filtered and stored under $4^{\circ}$ temperature before use.

All mentioned application techniques demonstrated positive results in controlling certain insect pests. These efforts have been done in few parts of developing countries despite presence of pesticidal plants in diverse areas. These calls for diverse research of plants with pesticidal properties coupled with indigenous knowledge from different domains and develop tangible solutions on the use of pesticidal plants to control insect pests.

\section{Characterizing Toxicity in Selected Botanical Plants}

Four plant species, Tephrosia vogelii, Vernonia amygdalina, Tithonia diversifolia and Lantana camara will be described. The mentioned plants have been tested for their efficacy in the control of insect pests in field and on storage of food crops [50]. They are also massively available in rural environments on roadsides and farm boundaries. Research that builds up from what small scale farmers understand about these plant species is needed in order to improve knowledge with a scientific basis for more reliable use of the technology. Therefore, it is worthy conducting research basing on the preparation techniques suggested in the literatures to several other crops and insect pests as well as introducing more favorable techniques that are reliable to small scale farmers.

\subsection{Lantana camara}

Lantana camara is reported to have toxicity effects to animals and is also a noxious plant species that has been cited as invasive in need monitoring [51]. Literatures report that Lantana causes less mobility, dehydration and constipation, congested heart and lung, nephrosis, general reproductive performance and teratology to mice [52]. Lantana is also reported to have a fumigant effects [53] [54] and has been revealed for its water purification potential. Lantana camara contains a compound known as ursolic acid stearoylglucoside (UASG) depicted in Figure 1, that is associated with toxicity and which includes triterpenoids in the apolar phase [54].

In agriculture, Lantana camara has been used for the control of insect pests in stored grains [56] [57]. Lanta$n a$ has also been tested for its repellent, antifeedant and toxicity against termites [58]. All these experiments are laboratory based. Hence there is a need for more practical research on the field to test for the effectiveness of $L$. camara against field insect pests. Furthermore, use, use, use of Lantana camara for beneficial effects will help reduce its invasive property to farm lands.

\subsection{Tephrosia vogelii}

Tephrosia vogelii is widely used for control of pests and as a source of nutrients to the soil [59]. Leaf extract of T.vogelii is reported to exhibit toxicity against Tilapia nilotica [60]. This is practiced in remote areas of Africa, commonly regarded as illegal fishing [61]. It is reported that leaves of $T$. vogelii contain high amounts of rotenone and deguelin [62] responsible for the toxicity to fish. Tephrosia vogelii has however a great potential in agriculture in the control of insect pests and in soil enrichment through nitrogen fixation [59].

Diverse compounds exist in the plant and according to [63] this plant consist of chemotype 1 (C1) and chemotype 2 (C2) (Figure 2) of which $\mathrm{C} 1$ is found to be active against insect pests. In additional to insect pest 


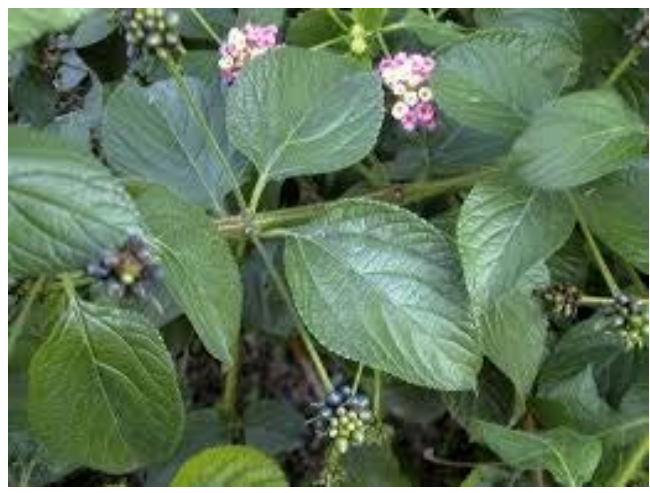

Botany picture of Lantana camara.

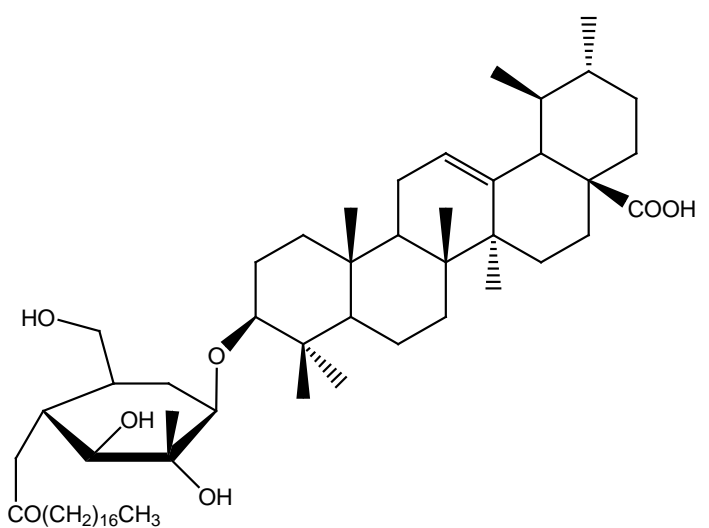

Figure 1. A chemical structure of ursolic acid stearoylglucoside (UASG) (Source, [55]).

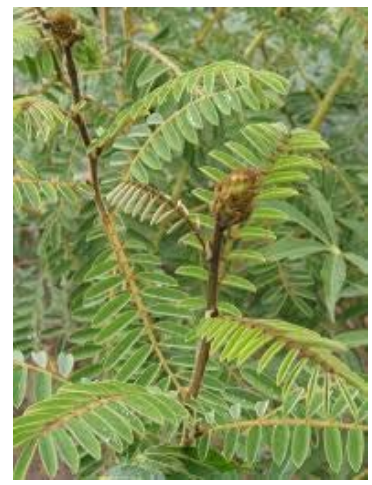

Botany pictures of Tephrosia vogelii.

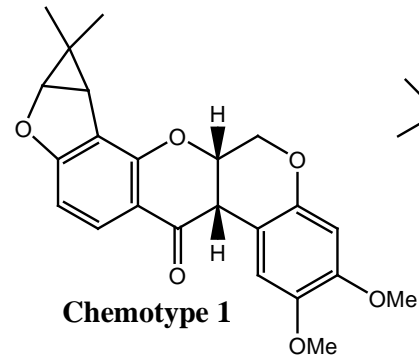<smiles>COc1cc2c(c3c1C(=O)C[C@H](c1ccccc1)O3)CCC(C)(C)O2</smiles>

Figure 2. Compound structure of chemotype 1 (C1) and chemotype 2 (C2) of Tephrosia vogelii (Source: [59]). 
control, mulches of the plant have increased maize biomass while decreasing the weed biomass [63]. Therefore, this makes $T$. vogelii to have herbicidal, pesticidal effects and again as a fertilizer [64]. More studies support the activity of T. vogelii in insects. [65] has confirmed its insecticidal, antifeedant and repellent effects against golden flea beetle that represent a group of insects.

Tephrosia vogelii is a legume, that has higher proliferation rates and this is potential to small scale farmers that has less cost to grow and process for insect pests control in agriculture.

\subsection{Vernonia amygdalina}

Vernonia amygdalina is reported to contain useful compounds such as vernolide and vernodalol, epivernodalol [66]; Figure 3), kolaviron [67] as useful phytochemicals.

Vernonia amygdalina is reported to be effective against bacteria, fungi and virus species [66], as an anticancer, anti-malaria and as anti-diabetic antioxidant agent and also used as vegetable [68]-[70].

Vernonia amygdalina has been reported as a pesticidal plant, in the treatment of been weevils where ethanoic extracts showed activity [71]. Several other compounds such as saponins and alkaloids, terpenes, steroids, coumarins, flavonoids, phenolic acids, lignans, xanthones, anthraquinones, edotides and sesquiterpenes have been identified from this plant [67] [72]. More studies on identification of useful compounds from V. amygdalina and testing their efficacy against field and storage crops is of paramount importance.

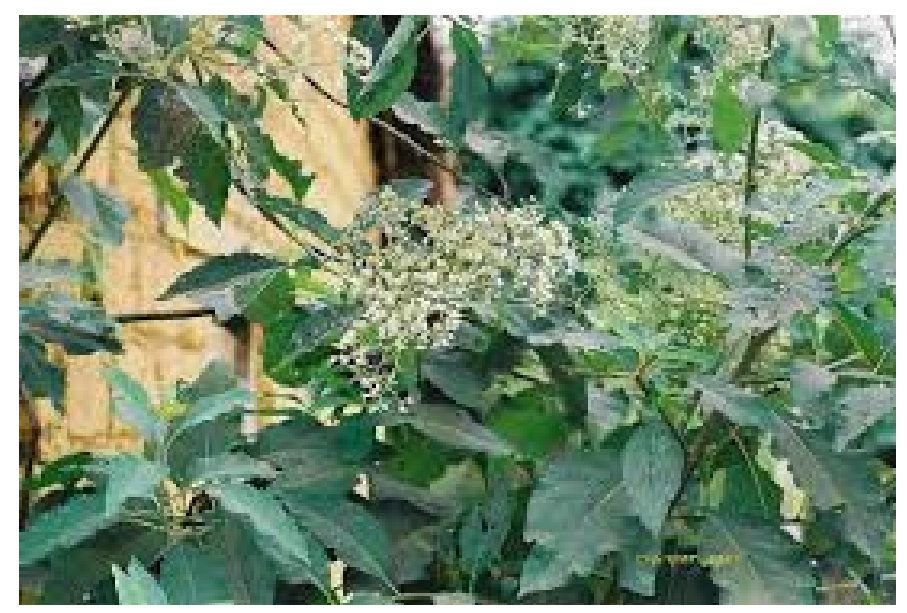

Botany picture of Vernonia amygdalina<smiles>C=CC12COC(=O)C(=C)C1(C)C1OC(=O)C(=C)C1C(OC(=O)C(=C)CO)C2</smiles>

Vernodalin<smiles>C=CC12COC(=O)C(=C)C1(C)C(O)C(C(=C)OC)C(OC(=O)C(=C)CO)C2</smiles><smiles>C=C[C@]12COC(=O)C(=C)[C@@]1(C)[C@@H](C)[C@@H](C(=C)C(=O)OC)[C@@H](OC(=O)C(=C)CO)C2</smiles>

Epivernodalol

Figure 3. Structures of isolated compounds from Vernonia amygdalina (Source: [67]). 


\subsection{Tithonia diversifolia}

Tithonia diversifolia is a well known traditional plant in developing countries. It is renowned to have agricultural benefits such as higher phosphorous contents in the above ground biomass [73], insecticidal effects [74], anti-malarial, and anti-inflammation. It is also used as ruminant fodder [75] [76]. T. diversifolia contain many compounds. [77] found about 16 compounds while [78] review about 150 compounds of Tithonia and 150 compounds of Tithonia diversifolia. Some of them are shown in Figure 4.

T. diversifolia has been tested for its biochemical and toxicological effects. In China, T. diversifolia has been reported to treat, diabetes, hepatitis, and hepatocarcinoma although the mechanism involved is not yet understood [79]. In agriculture, chopped pieces of stem and leaves of T. diversifolia have showed a significant increase in soil P, Ca, CEC, K and soil organic matter content [73].

Another study by [80] showed that Tithonia diversifolia has phytoremediation potential with a capacity to accumulate $\mathrm{Pb}$ and $\mathrm{Zn}$ from the soil to the shoots. This ability gives room for study on the possible capacity of the plant in the remediation of degraded soils from synthetic pesticides contamination.

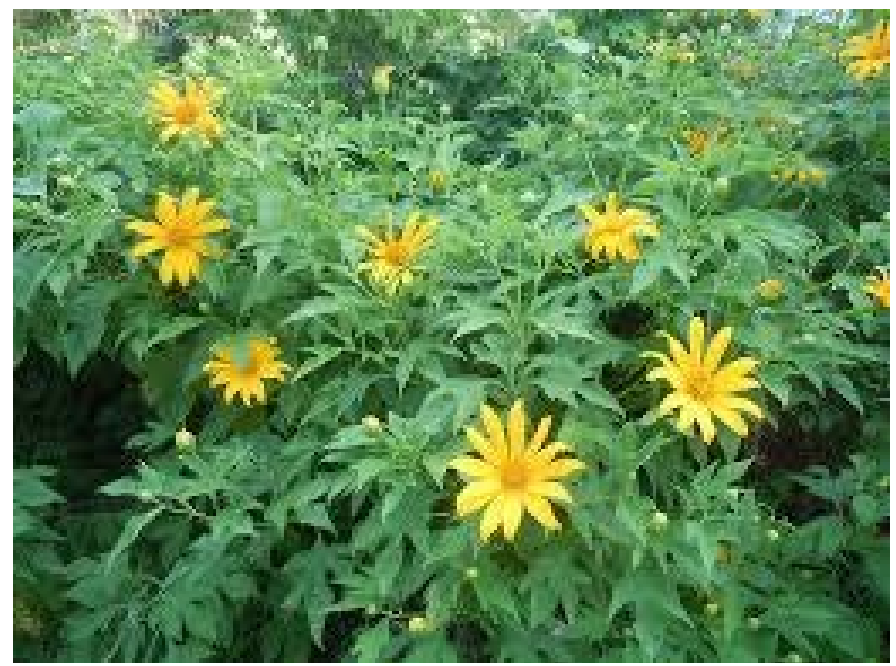

Botany picture of Tithonia diversifolia.
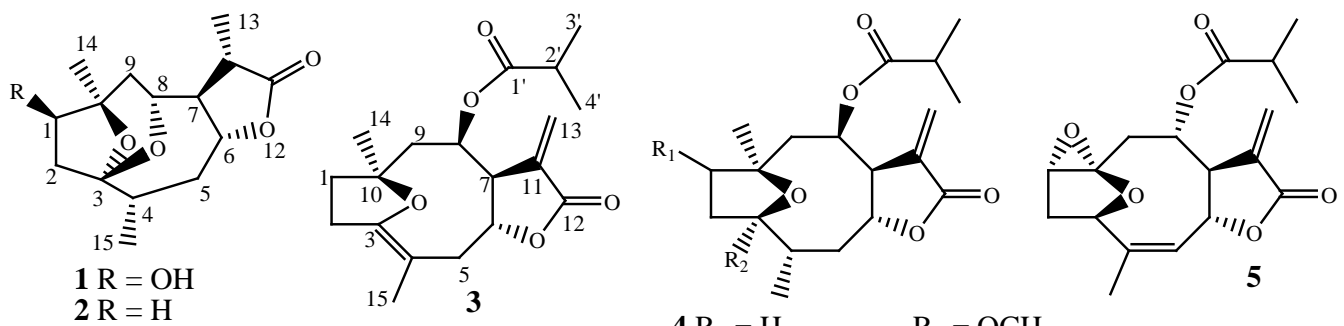

$$
\begin{array}{ll}
\mathbf{4} \mathrm{R}_{1}=\mathrm{H} & \mathrm{R}_{2}=\mathrm{OCH}_{3} \\
\mathbf{8} \mathrm{R}_{1}=\text { alpha } \mathrm{OH} & \mathrm{R}_{2}=\mathrm{OCH}_{3}
\end{array}
$$
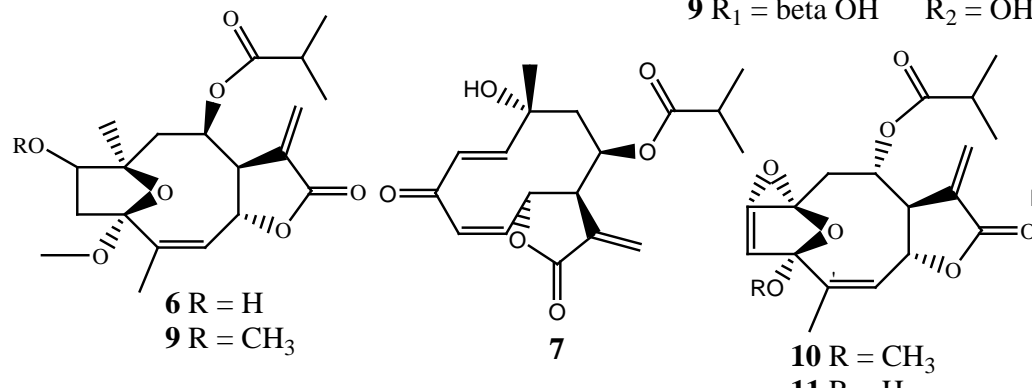<smiles>[R]O[C@]1(C)[C@@H](O)CC[C@]2(C)CC[C@@H](C(=C)C(=O)O)C[C@@]21C</smiles>

$10 \mathrm{R}=\mathrm{CH}_{3}$

$13 \mathrm{R}=\mathrm{OAC}$

$14 \mathrm{R}=\mathrm{H}$

Figure 4. 1-14 compounds found in Tithonia diversifolia (Source: [77]). 


\section{Research Needs and Conclusion}

The fact that small holder farmers have the knowledge of using pesticidal plants which they hardly use, there is a need of a research based solution on better ways to make the knowledge useful. Practical research based in field situation and that directly involve small scale farmers is important to put into practice experts' understanding. Pesticidal plants contain some degree of toxicity. It is important to understand their persistence to the environment in order to establish clear intervals of application and to make farmers aware of proper ways of preparation and use for health and environmental safety.

\section{References}

[1] Isman, M.B. (2008) Botanical Insecticides: For Richer, for Poorer. Pest Management Science, 64, 8-11. http://dx.doi.org/10.1002/ps.1470

[2] Dubey, N.K., Srivastava, B. and Kumar, A. (2008) Current Status of Plant Products as Botanical Pesticides in Storage Pest Management. Journal of Biopesticides, 1, 182-186.

[3] Sola, P., Mvumi, B.M., Ogendo, J.O., Mponda, O., Kamanula, J.F., Nyirenda, S.P., Belmain, S.R. and Stevenson, P.C. (2014) Botanical Pesticide Production, Trade and Regulatory Mechanisms in Sub-Saharan Africa: Making a Case for Plant-Based Pesticidal Products. Food Security, 6, 369-384. http://dx.doi.org/10.1007/s12571-014-0343-7

[4] Grzywacz, D., Stevenson, P.C., Mushobozi, W.L., Belmain, S. and Wilson, K. (2014) The Use of Indigenous Ecological Resources for Pest Control in Africa. Food Security, 6, 71-86. http://dx.doi.org/10.1007/s12571-013-0313-5

[5] Gakuya, D.W., Itonga, S.M., Mbaria, J.M., Muthee, J.K. and Musau, J.K. (2013) Ethnobotanical Survey of Biopesticides and Other Medicinal Plants Traditionally Used in Meru Central District of Kenya. Journal of Ethnopharmacology, 145, 547-553. http://dx.doi.org/10.1016/j.jep.2012.11.028

[6] Van Andel, T.R., Croft, S. and van Loon, E.E. (2015) Prioritizing West African Medicinal Plants for Conservation and Sustainable Extraction Studies Based on Market Surveys and Species Distribution Models. Biological Sciences, 181, 173-181.

[7] Dunlap, T. (2014) DDT Scientists, Citizens, and Public Policy. Princeton University Press, UK.

[8] Isman, M.B. (2006) Botanical Insecticides, Deterrents, and Repellents in Modern Agriculture and an Increasingly Regulated World. Annual Review of Entomology, 51, 45-66. http://dx.doi.org/10.1146/annurev.ento.51.110104.151146

[9] Dinham, B. (2003) Growing Vegetables in Developing Countries for Local Urban Populations and Export Markets: Problems Confronting Small-Scale Producers. Pest Management Science, 5, 575-582. http://dx.doi.org/10.1002/ps.654

[10] Gonzalez, R.H. (1999) Pesticides Residues in Developing Countries-A Review of Residues Detected in Food Exports from the Developing World. In: Brook, G. and Roberts, T., Eds., Pesticide Chemistry and Bioscience: The Food-Environment Challenge, The Royal Society of Chemistry, UK, 386-401. http://dx.doi.org/10.1533/9781845698416.8.386

[11] Mazid, S. (2011) Review on the Use of Biopesticides in Insect Pest Management. International Journal of Science and Advanced Technology, 1, 169-178.

[12] Dubey, N.K. (2011) Natural Products in Plant Pest Management.

[13] Nyirenda, S.P. and Sileshi, G.W. (2011) Farmers' Ethno-Ecological Knowledge of Vegetable Pests and Pesticidal Plant Use in Malawi and Zambia. African Journal of Agricultural Research, 6, 1525-1537.

[14] Belmain, S. and Stevenson, P. (2001) Ethnobotanicals in Ghana: Reviving and Modernizing Age-Old Farmer, Practice. Pesticide Outlook, 12, 233-238. http://dx.doi.org/10.1039/b110542f

[15] Paul, U.V., Lossini, J.S., Edwards, P.J. and Hilbeck, A. (2009) Effectiveness of Products from Four Locally Grown Plants for the Management of Acanthoscelides Obtectus (Say) and Zabrotes Subfasciatus (Boheman) (Both Coleoptera: Bruchidae) in Stored Beans under Laboratory and Farm Conditions in Northern Tanzania. Journal of Stored Products Research, 45, 97-107. http://dx.doi.org/10.1016/j.jspr.2008.09.006

[16] Stevenson, P.C., Nyirenda, S.P., Mvumi, B., Sola, P., Kamanula, J.M., Sileshi, G. and Belmain, S.R. (2012) Pesticidal Plants: A Viable Alternative Insect Pest Management Approach for Resource-Poor Farming in Africa. In: Koul, O., Khokhar, S., Dhaliwal, D.S. and Singh, R., Eds., Biopesticides in Environment and Food Security, Scientific Publishers, Jodhpur, 212-238.

[17] Wang, L., Wei, K., Jiang, Y. and Cheng, H. (2011) Seasonal Climate Effects on Flavanols and Purine Alkaloids of Tea (Camellia sinensis L.). European Food Research and Technology, 233, 1049-1055. http://dx.doi.org/10.1007/s00217-011-1588-4

[18] Miresmailli, S. and Isman, M.B. (2014) Botanical Insecticides Inspired by Plant-Herbivore Chemical Interactions. Trends in Plant Science, 19, 29-35. http://dx.doi.org/10.1016/j.tplants.2013.10.002

[19] Paul, V.P. (2007) Bean Pest Management in East Africa: A Scientific Evaluation of Organic Insect Control Practices 
Used by Tanzanian Farmers. Doctoral Thesis, Swiss Federal Institute of Technology, Zurich.

[20] Amoabeng, B.W., Geoff, M.G., Catherine, W.G., Helen, I.N. and Louis, M. (2013) Tri-Trophic Insecticidal Effects of African Plants against Cabbage Pests. PLoS ONE, 8, e78651.

[21] Mekonnen, M., Begashaw, M. and Beemnet, M. (2014) Screening of Botanical Extracts for the Control of Spearmint Leaf Rust in Greenhouse and Field Conditions. World Journal of Agricultural Sciences, 10, $42-47$.

[22] Mugisha-Kamatenesi, M., Deng, A.L., Ogendo, J.O., Omolo, E.O., Mihale, M.J., Otim, M., Buyungo, J.P. and Bett, P.K. (2008) Indigenous Knowledge of Field Insect Pests and Their Management around Lake Victoria Basin in Uganda. African Journal of Environmental Science and Technology, 2, 342-348.

[23] Mihale, M.J., Deng, A.L., Selemani, H.O., Mugisha-Kamatenesi, M., Kidukuli, A.W. and Ogendo, J.O. (2009) Use of Indigenous Knowledge in the Management of Field and Storage Pests around Lake Victoria Basin in Tanzania. African Journal of Environmental Science and Technology, 3, 251-259.

[24] Panghal, M., Arya, V., Yadav, S., Kumar, S. and Yadav, J.P. (2010) Indigenous Knowledge of Medicinal Plants Used by Saperas Community of Khetawas, Jhajjar District, Haryana, India. Journal of Ethnobiology and Ethnomedicine, 6, 4. http://dx.doi.org/10.1186/1746-4269-6-4

[25] Zacharia, J.T., Kishimba, M.A. and Masahiko, H. (2010) Biota Uptake of Pesticides by Selected Plant Species; the Case Study of Kilombero Sugarcane Plantations in Morogoro Region, Tanzania. Pesticide Biochemistry and Physiology, 97, 71-75. http://dx.doi.org/10.1016/j.pestbp.2010.01.001

[26] Ngowi, A.V.F., Mbise, T.J., Ijani, A.S.M., London, L. and Ajayi, O.C. (2007) Smallholder Vegetable Farmers in Northern Tanzania: Pesticides Use Practices, Perceptions, Cost and Health Effects. Crop Protection, 26, 1617-1624. http://dx.doi.org/10.1016/j.cropro.2007.01.008

[27] Naidoo, S., Kromhout, H., London, L., Naidoo, R.N. and Burdorf, A. (2011) Musculoskeletal Pain in Women Working in Small-Scale H Agriculture in South Africa. American Journal of Industrial Medicine, 52, 202-209. http://dx.doi.org/10.1002/ajim.20662

[28] Regnault-Roger, C. (2012) Essential Oils in Insect Control: Low-Risk Products in a High-Stakes World. Annual Review of Entomology, 57, 405-424. http://dx.doi.org/10.1146/annurev-ento-120710-100554

[29] Miah, S.J., Hoque, A., Paul, A. and Rahman, A. (2014) Unsafe Use of Pesticide and Its Impact on Health of Farmers: A Case Study in Burichong Upazila, Bangladesh. IOSR Journal of Environmental Science, Toxicology and Food Technology, 8, 57-67. http://dx.doi.org/10.9790/2402-08155767

[30] Athukorala, W., Clevo, W., and Tim, R. (2012) Determinants of Health Costs Due to Farmers' Exposure to Pesticides: An Empirical Analysis. Journal of Agricultural Economics, 63, 158-174. http://dx.doi.org/10.1111/j.1477-9552.2011.00326.x

[31] Bolognesi, C. and Merlo, F.D. (2011) Pesticides: Human Health Effects. In: Nriagu, J.O., Ed., Encyclopedia of Environmental Health, Elsevier, Burlington, 438-453. http://dx.doi.org/10.1016/b978-0-444-52272-6.00592-4

[32] Saxena, P. (2014) Comparative Prediction of Binding Site of Organophosphorus, Carbamate and Synthetic Pyrethroid Pesticides on Human Cyclin-Dependent Protein Kinases. Journal of Entomology and Zoology Studies, 2, 106-110.

[33] Mitra, A., Chandranath, C. and Fatik, B.M. (2011) Synthetic Chemical Pesticides and Their Effects on Birds. Research Journal of Environmental Toxicology, 5, 81-96. http://dx.doi.org/10.3923/rjet.2011.81.96

[34] Malhat, F.M., Haggag, M.N. and Loutfy, N.M. (2015) Residues of Organochlorines and Synthetic Pyrethroid Pesticides in Honey, an Indicator of Ambient Environment, a Pilot Study. Chemosphere, 120, 457-461. http://dx.doi.org/10.1016/j.chemosphere.2014.08.032

[35] Roca, M., Miralles-Marco, A. and Ferré, J. (2014) Biomonitoring Exposure Assessment to Contemporary Pesticides in a School Children Population of Spain. Environmental Research, 131, 77-85. http://dx.doi.org/10.1016/j.envres.2014.02.009

[36] Attfield, K.R. and Hughes, M.D. (2014) Within- and Between-Child Variation in Repeated Urinary Pesticide Metabolite Measurements over a 1-Year Period. Environmental Health Perspectives, 122, 201-206.

[37] Johnson, R.M., Ellis, M.D., Mullin, A.C. and Frazier, M. (2010) Review Article Pesticides and Honey Bee ToxicityUSA. Apidologie, 41, 312-331. http://dx.doi.org/10.1051/apido/2010018

[38] Wu, J.Y., Carol, M.A. and Walter, S.S. (2011) Sub-Lethal Effects of Pesticide Residues in Brood Comb on Worker Honey Bee (Apis mellifera) Development and Longevity. PLoS ONE, 6, e14720. http://dx.doi.org/10.1371/journal.pone.0014720

[39] Jenkins, S., Ary, A., Hoffmann, S.M., Angelos, T. and Paul, A.U. (2013) Synthetic Pesticides in Agro-Ecosystems: Are They as Detrimental to Nontarget Invertebrate Fauna as We Suspect. Journal of Economic Entomology, 106, 756-775. http://dx.doi.org/10.1603/EC12088

[40] Weichenthal, S., Connie, M. and Peter, C. (2010) A Review of Pesticide Exposure and Cancer Incidence in the Agricultural Health Study Cohort. Environmental Health Perspectives, 118, 1117-1125. 
http://dx.doi.org/10.1289/ehp.0901731

[41] Mnif, W., Hassine, A.I.H., Bouaziz, A., Bartegi, A., Thomas, O. and Roig, B. (2011) Effect of Endocrine Disruptor Pesticides: A Review. International Journal of Environmental Research and Public Health, 8, 2265-2303. http://dx.doi.org/10.3390/ijerph8062265

[42] Watson, S.L. (2014) Assessing the Impacts of Unrestricted Pesticide Use in Small-Scale Agriculture on Water Quality and Associated Human Health and Ecological Implications in an Indigenous Village in Rural Panam (Aacute). Graduate Thesis, University of South Florida, Tampa.

[43] Fuad, M.J.M., Junaidi, A.B., Habibah, A., Hamzah, J., Toriman, M.E., Lyndon, N., Er, A.C., Selvadurai, S. and Azima, A.M. (2012) The Impact of Pesticides on Paddy Farmers And Ecosystem. Advances in Natural and Applied Sciences, 6 , 65-70.

[44] Wilson, C. and Tisdell, C. (2001) Why Farmers Continue to Use Pesticides Despite Environmental, Health and Sustainability Costs. Ecological Economics, 39, 449-462. http://dx.doi.org/10.1016/S0921-8009(01)00238-5

[45] Lodhi, S. and Mikulecky, P. (2010) Management of Indigenous Knowledge for Developing Countries. International Conference on Communication and Management in Technological Innovation and Academic Globalization, Puerto De La Cruz, 30 November-2 December 2010, 94-98.

[46] Sukula, S.K. (2006) Developing Indigenous Knowledge Databases in India. The Electronic Library, 24, 83-93. http://dx.doi.org/10.1108/02640470610649263

[47] El-Wakeil, N.E. (2013) Botanical Pesticides and Their Mode of Action. Gesunde Pflanzen, 65, 125-149. http://dx.doi.org/10.1007/s10343-013-0308-3

[48] Prakash, A., Rao, J. and Nandagopal, V. (2008) Future of Botanical Pesticides in Rice, Wheat, Pulses and Vegetables Pest Management. Journal of Biopesticides, 1, 154-169.

[49] Amoabeng, B.W., Geoff, M.G., Catherine, W.G. and Philip, C.S. (2014) Cost: Bene Fit Analysis of Botanical Insecticide Use in Cabbage: Implications for Smallholder Farmers in Developing Countries. Crop Protection, 57, 71-76. http://dx.doi.org/10.1016/j.cropro.2013.11.019

[50] Mkenda, P.A., Kelvin, M. and Patrick, A.N. (2014) Pesticidal Efficacy of Tephrosia Vogelii and Tithonia Diversifolia against Field Insect Pests of Common Beans [Phaseolus vulgaris L.] within African Farming Communities. African Journal of Applied Agricultural Sciences and Technology, 2, 9-26.

[51] Baars, J.R. and Neser, S. (1999) Past and Present Initiatives on the Biological Control of Lantana camara (Verbenaceae) in South Africa. African Entomology Memoir, No. 1, 21-33.

[52] Mello, F.B., Daniela, J., Kelly, C. and João, R.B.M. (2005) Effects of Lantana camara (Verbenaceae) on General Reproductive Performance and Teratology in Rats. Toxicon: Official Journal of the International Society on Toxinology, 45, 459-466. http://dx.doi.org/10.1016/j.toxicon.2004.12.004

[53] Zoubiri, S. and Baaliouamer, A. (2012) GC and GC/MS Analyses of the Algerian Lantana camara Leaf Essentia Oil: Effect against Sitophilus Granarius Adults. Journal of Saudi Chemical Society, 16, 291-297. http://dx.doi.org/10.1016/j.jscs.2011.01.013

[54] Bevilacqua, A.H.V., Suffredini, I.B., Romoff, P., Lago, J.H.G. and Bernardi, M.M. (2011) Toxicity of Apolar and Polar Lantana camara L. Crude Extracts in Mice. Research in Veterinary Science, 90, 106-115. http://dx.doi.org/10.1016/j.rvsc.2010.05.001

[55] Kazmi, I., Afzal, M., Ali, B., Damanhouri, Z.A., Ahmaol, A. and Anwar, F. (2013) Anxiolytic Potential of Ursolic Acid Derivative-A Stearoyl Glucoside Isolated from Lantana camara L. (Verbanaceae). Asian Pacific Journal of Tropical Medicine, 6, 433-437. http://dx.doi.org/10.1016/S1995-7645(13)60069-3

[56] Rajashekar, Y., Raghavendra, A. and Bakthavatsalam, N. (2014) Acetylcholinesterase Inhibition by Biofumigant (Coumaran) from Leaves of Lantana camara in Stored Grain and Household Insect Pests. BioMed Research International, 2014, Article ID: 187019.

[57] Rajashekar, Y., Honnaiah, V., Kothapalli, V.R. and Nandagopal, B. (2013) Isolation and Characterization of Biofumigant from Leaves of Lantana camara for Control of Stored Grain Insect Pests. Industrial Crops \& Products, 51, $224-$ 228. http://dx.doi.org/10.1016/j.indcrop.2013.09.006

[58] Yuan, Z. and Xing, P.H. (2012) Repellent, Antifeedant, and Toxic Activities of Lantana camara Leaf Extract against Reticulitermes Flavipes (Isoptera: Rhinotermitidae). Journal of Economical Entomology, 105, 2115-2121. http://dx.doi.org/10.1603/EC12026

[59] Stevenson, P.C., Kite, G.C. and Lewis, G.P. (2012) Distinct Chemotypes of Tephrosia Vogelii and Implications for Their Use in Pest Control and Soil Enrichment. Phytochemistry, 78, 135-146. http://dx.doi.org/10.1016/j.phytochem.2012.02.025

[60] Ibrahim, B. and M’batchi, B. (2000) Effect of Tephrosia vogelii and Justicia extensa on Tilapia nilotica in Vivo. Jour- 
nal of Ethnopharmacology, 69, 99-104. http://dx.doi.org/10.1016/S0378-8741(99)00036-7

[61] Neuwinger, H.D. (2004) Plants Used for Poison Fishing in Tropical Africa. Toxicon, 44, 417-430. http://dx.doi.org/10.1016/j.toxicon.2004.05.014

[62] Kalume, M.K., Losson, B. and Angenot, L. (2012) Rotenoid Content and in Vitro Acaricidal Activity of Tephrosia Vogelii Leaf Extract on the Tick Rhipicephalus Appendiculatus. Veterinary Parasitology, 190, 204-209. http://dx.doi.org/10.1016/j.vetpar.2012.06.015

[63] Belmain, S.R., Barbara, A.A., Stephen, P., Nyirenda, J.F.K. and Philip, C.S. (2012) Highly Variable Insect Control Efficacy of Tephrosia vogelii Chemotypes. Journal of Agricultural and Food Chemistry, 60, 10055-10063. http://dx.doi.org/10.1021/jf3032217

[64] Wang, R.L., Yang, X.Y., Song, Y.Y., Zhang, M.X., Hu, L., Su, Y.J. and Zeng, R. (2011) Allelopathic Potential of Tephrosia vogelii Hook. F.: Laboratory and Field Evaluation. Allelopathy Journal, 28, 53-62.

[65] Igogo, J.M., Ogendo, J.O., Kariuki, S.T. and Otaye, D.O. (2011) Insecticidal, Antifeedant and Repellent Effects of Tephrosia vogelii Hook, and Lantana camara L. Aqueous Crude Extracts against Golden Flea Beetle, Aphthona Whitfieldi Bryant in Jatropha, Jatropha curcas L. Biopesticides International, 7, 93-103.

[66] Erasto, P., Grierson, D. and Afolayan, A. (2006) Bioactive Sesquiterpene Lactones from the Leaves of Vernonia Amygdalina. Journal of Ethnopharmacology, 106, 117-120. http://dx.doi.org/10.1016/j.jep.2005.12.016

[67] Farombi, E.O. and Olatunde, O. (2011) Antioxidative and Chemopreventive Properties of Vernonia Amygdalina and Garcinia Biflavonoid. International Journal of Environmental Research and Public Health, 8, 2533-2555. http://dx.doi.org/10.3390/ijerph8062533

[68] Cameron, K.S., Howard, C.B. and Izevbigie, E.B. (2013) Sensitivity and Mechanisms of Taxol-Resistant Prostate Adenocarcinoma Cells to Vernonia Amygdalina Extract. Toxicologic Pathology, 65, 759-765. http://dx.doi.org/10.1016/j.etp.2012.11.002

[69] Owolabi, M.A., Jaja, S.I. and Olatunji, O.J. (2011) Attenuation of Oxidative Damage in Alloxan Induced Diabetic Rabbits Following Administration of the Extract of the Leaves of Vernonia Amygdalina. Free Radicals and Antioxidants, 1, 94-101. http://dx.doi.org/10.5530/ax.2011.3.13

[70] Yeap, S.K., Ho, W.Y. and Beh, B.K. (2010) Vernoniaamygdalina, an Ethnoveterinary and Ethnomedical Used Green Vegetable with Multiple Bioactivities. Journal of Medicinal Plants Research, 4, 2787-2812.

[71] Adeniyi, S.A., Orjiekwe, C.L., Ehiagbonare, J.E. and Arimah, B.D. (2010) Preliminary Phytochemical Analysis and Insecticidal Activity of Ethanolic Extracts of Four Tropical Plants Weevil (Acanthscelides obtectus). International Journal of the Physical Sciences, 6, 753-762.

[72] Ong, K., Hsu, A. and Song, L. (2011) Polyphenols-Rich Vernonia amygdalina Shows Anti-Diabetic Effects in Streptozotocin-Induced Diabetic Rats. Journal of Ethno Pharmacology, 133, 598-607. http://dx.doi.org/10.1016/j.jep.2010.10.046

[73] Shokalu, A.O., Ojo, A.O., Adewoyin, D.T.E. and Azeez, A.J. (2010) Evaluation of Tithonia Diversifolia for Soil Improvement in Celosia (Celosia argentea) Production. Electronic Journal of Environmental, Agricultural and Food Chemistry, 9, 951-957.

[74] Casta-o-Quintana, K., Montoya-Lermaa, J. and Giraldo-Echeverrib, C. (2013) Toxicity of Foliage Extracts of Tithonia Diversifolia (Asteraceae) on Atta Cephalotes (Hymenoptera: Myrmicinae) Workers. Industrial Crops and Products, 44, 391-395. http://dx.doi.org/10.1016/j.indcrop.2012.11.039

[75] De Toledo, J.S., Ambrósio, S.R., Borges, C.H.G., Manfrim, V., Cerri, D.G., Cruz, A.K., Da Costa, F.B., De Toledo, J.S. and Da Costa, F.B. (2014) In Vitro Leishmanicidal Activities of Sesquiterpene Lactones from Tithonia Diversifolia against Leishmania Braziliensis Promastigotes and Amastigotes. Molecules, 19, 6070-6079. http://dx.doi.org/10.3390/molecules19056070

[76] Pérez, A., Montejo, I., Iglesias, J., López, O., Martín, G., García, D., Milián, I. and Hernández, A. (2009) Tithonia diversifolia (Hemsl.) A. Gray. Pastos y Forrajes, 32, 1.

[77] Zhao, G., Li, X., Chen, W., Xi, Z. and Sun, L. (2012) Three New Sesquiterpenes from Tithonia diversifolia and Their Anti-Hyperglycemic Activity. Fitoterapia, 83, 1590-1597. http://dx.doi.org/10.1016/j.fitote.2012.09.007

[78] Chagas-Paula, D.A., Oliveira, R.B., Rocha, B.A. and Fernando, B.D. (2012) Ethnobotany, Chemistry, and Biological Activities of the Genus Tithonia (Asteraceae). Chemistry and Biodiversity, 9, 210-235. http://dx.doi.org/10.1002/cbdv.201100019

[79] Lin, H.R. (2012) Sesquiterpene Lactones from Tithonia diversifolia Act as Peroxisome Proliferator-Activated Receptor Agonists. Bioorganic and Medicinal Chemistry Letters, 22, 2954-2958. http://dx.doi.org/10.1016/j.bmcl.2012.02.043

[80] Adesodun, J.K., Atayese, M.O., Agbaje, T.A., Osadiaye, B.A., Mafe, O.F. and Soretire, A.A. (2010) Phytoremediation Potentials of Sunflowers (Tithonia diversifolia and Helianthus annuus) for Metals in Soils Contaminated with Zinc and Lead Nitrates. Water, Air, and Soil Pollution, 207, 195-201. http://dx.doi.org/10.1007/s11270-009-0128-3 